\title{
Resource Sharing among Polytechnic Libraries in Ghana
}

\author{
Faustina Kyerewaa Barfi \\ Accra Polytechnic Library, P. O. Box GP 561, Accra \\ Email:faustinabarfi@yahoo.co.uk
}

\begin{abstract}
The paper presents a synthesis on resource sharing among polytechnic libraries in Ghana. It explores how resource sharing would provide opportunities for the consolidation of strengths and minimize weakness among the polytechnic libraries. The main objective of resource sharing is to maximise the availability of materials and services and to minimize expenses and duplication. The paper further exposed some of the factors which make resource sharing imperative among the polytechnic libraries. These concerns include the proliferation of knowledge on the World Wide Web, issues of distance education, open access and instruction service. It also highlighted some of the resources that could be shared among the polytechnic libraries which include personnel, electronic service, tools, professional activities, policies, etc. Finally techniques that would foster resource sharing activities among the polytechnic libraries were discussed and these include communication, increase in the use of information communication technology, resource mobilisation and capacity building on the part of librarians.
\end{abstract}

Keywords: Co-operation; Information sharing; Consortia formation; Academic libraries networking.

\section{Introduction}

Nowadays, no individual or group can profitably remain an island by itself. This explains the various forms of co-operation that exist not only among individuals and groups that share common cultural, economic and values, but also among those that pursue different and sometimes contrary policies. Aina (2004) defined resource sharing as any activity shared by two or more libraries to facilitate, improve and develop library operations that would enhance the exploitation of library resources and services by their users. According to him, resources such as electronic databases, personnel, service tools, bibliographical databases, collection management practices, professional activities, intellectual content, policies, etc can be shared in order to facilitate access.

Within the context of library, Wilson and Marterson (1970) further defined resource sharing as the exchange, coalition and reciprocal beneficial sharing of resources, which spans to include interlending and the referral of enquirers, Co-operative acquisition, Co-operative storage, Training, Exchange of materials, Exchange of users, Exchange of information, Joint production of service tools, Joint funding of services, etc.

A library is adjudged to have achieved its mandate when its users are satisfied with the services offered them. According to Akwa (2005), most academic libraries in Ghana have limited ability to meet the needs of their users due to such realities as limited financial resources, changes in technology, inadequate storage facilities, proliferation of literature, and the absence of information technology. As a result of these, libraries have now been compelled to share their resources within certain framework to meet users' needs.

Globally, no library can claim bibliographic completeness in its collection development, therefore resource sharing has become an important option out of the problem. This paper aims to highlight the stateof-the-art in resource sharing among polytechnic libraries in order to determine the level of sufficiency and effectiveness of this service. Similarly, in this paper, factors militating against resource sharing within the polytechnic libraries are examined with suggestions on how such problems could be addressed.

\section{Some challenges of polytechnic libraries in Ghana}

Academic libraries seem to have common problems irrespective of their buildings, professional staff, collection development, etc. Among the academic libraries are polytechnic libraries which 
serve as the main source of information in their localities. Polytechnic libraries are suppose to acquire, process and disseminate scholarly materials to support teaching, learning and research.

In spite of these, the rapid changes in technology have posed a challenge for these libraries to deliver effectively. According to Yakubu (2010), libraries play a central role in the development of academic and research institutions and that it has increasingly become clear that academic and research libraries worldwide especially in Ghana, are undoubtedly in transition.

The challenge in information explosion and the rapid growth in the world literature along with problems such as shrinking library budgets, steady increase in document prices and depreciating currencies have made it difficult for academic libraries especially the polytechnic libraries in Ghana to acquire and retain most materials their users would use. This corroborated a report by Patterson (1993) that the cost of journal subscriptions has gone up at an average rate of $10 \%-15 \%$ per annum, while increase in the cost of serials in the field of science, technology and engineering are estimated at more than 15\% per year, hence resource sharing has become the obvious choice.

Further, the ever increasing number of people who need information urgently has resulted in an increase in the demand for the limited resources in our libraries. Henceforth, it is deduced from the above itemization that for exhaustive acquisition of materials, resource sharing is a viable option. Although some efforts have been made to meet a number of the challenges that confront these libraries, the challenge of the awareness of the existence of materials as well as literature in various formats poses threats to these Polytechnic libraries without resource sharing.

\section{Some studies on resource sharing activities in the world}

Resource sharing introduces an aspect of communication and information sharing between libraries and the user community.Aina (2004), believes that cooperation and resource sharing should be encouraged among libraries in order to avoid duplication. According to him it is impossible for individual libraries to acquire all the materials their users might need due to inadequate funds; hence resource sharing has become the only alternative solution.
Evans and Saponora (2005) are of the view that resource sharing facilitates access. They describe resource sharing as the activities engaged in jointly by a group of libraries for the purposes of improving access by making available a greater range of materials and also making it possible for libraries to stretch the limited resources. According to them, it can take the following forms:

i. Cooperative Collection Development is mechanism whereby two or more libraries agree to manage certain responsibility for the exchange of materials with one another free of charge.

ii. Coordinated Acquisition is where two or more libraries agree to buy certain materials and share the associated cost while one or more members house the materials.

iii. Shared Information is a system whereby m e mbers use information in a shared database about collection holdings to influence their selection.

Abass (2005) contended that resource sharing has been considered as one of the pillars of modern librarianship. Its main objective is to maximize cost and improve access by making available a greater range of materials or better in- depth of a subject area. According to him, it includes inter-library lending, corporative acquisition, shared storage, staff education, sharing of human resources, etc. Considering the various literatures reviewed, there seem to be pressure on the academic library's collection hence resources sharing has become a viable option.

\section{Current resource sharing initiatives in Ghana}

Resource sharing according to Alemna (2001) is considered as one of the pillars of modern librarianship. Owing to the exponential increase in world literature, resource sharing is the only logical, feasible and economical option to benefit from this huge pool of knowledge. Although academic libraries in Ghana acknowledge the advantages and benefits of resource sharing, practically the volume of this activity is far from satisfaction. (Alemna, 2001) Research has shown that the limited number of studies on this topic in Ghana restricts our understanding about the current status and the lack of any such study among the polytechnic libraries hinders its success. 
Throughout the development histories of academic libraries in Ghana, it is said that all of them have undergone one form of transformation or the other. Continuous changes in information landscape due to development in ICT have posed new and unexpected challenges as far as the new technology, new clientele and users are concerned. According to Entsua-Mensah (2010) sustainable solutions to address some of these challenges point towards cooperation which involves the coming together of libraries to share cost, build human capital through knowledge sharing and minimize duplication.

Fortunately in Ghana, this development has led to the formation of the Consortium of Academic and Research Libraries in Ghana (CARLIGH) which now allows members to pool their resources together to enable them to subscribe to electronic databases on regular basis. According to Entsua-Mensah (2010) through the consortium, full- text journal articles are made easily available to the academic staff, researchers and students in the respective institutions. Furthermore, the consortium has provided a logical framework for the academic libraries in Ghana to develop institutional repository using a common software packages to improve access to information. The mission of the Consortium of Academic and Research Libraries in Ghana is to employ collective information resources, through available technology and staff capabilities to improve teaching, learning and research within the universities, polytechnics and research libraries in Ghana.

\section{Challenges to resource sharing}

According to Agyei (2010) the following challenges have been identified to be associated with resource sharing among academic libraries in Ghana. These include inadequate skills, poor technological infrastructures, security issues and the mind set of some librarians. This statement is corroborated by Asamoah (1998) although some librarians are willing to team up to share resources, those in charge of the larger, libraries often believe that their users have little to gain from such a relationship which is a problem recognized by librarians in charge of small collection and therefore feel inhibited.

\section{Ways of fostering resource sharing}

White (2000) has instituted three ways in which resource sharing can be improved and these include:

Communication: For any type of co-operation activity to succeed, it is essential that polytechnic
Librarians communicate with each other. Librarians must create the platform and the opportunity for both senior and junior levels to communicate and thus could result in those Librarians identifying areas of common interest.

A clear understanding of roles: There must be a clear understanding of the roles of each polytechnic Library within the area and level of support each Library is able to offer to the other. For example, sharing of electronic databases, technology, funding, user education and interlending services.

Agreements on access are essential: regulations for admittance must be clear. Controlled access system which filters out enquirers whose demand can be satisfied elsewhere is necessary. Standard arrangements regarding referral should be established, perhaps making use of referral cards or letters.

Increased use of technology: Technology has had a considerable impact on Library resource sharing and would have a greater impact in future. A survey of Academic Libraries in Africa revealed that less than $30 \%$ are now using computer-based systems for cataloguing and circulation.(Odini, 1994).

According to Badu (1991) academic Libraries can only share resources well when they are automated. $\mathrm{He}$ asserted that at present few libraries within the academic environment are automated and some are in the process of doing so. Further dynamic and interactive websites indicated by Agyei (2010) should integrate library access services and user friendly interfaces.

Furtherance to this, Enstua-Mensah (2010) has also identified the following critical success factors upon which resource sharing can be viable. These include:

Resource mobilization planning: It is important for librarians to realise that there is a gradual shift from reliance on government subvention towards alternative funding sources. Therefore promotion and implementation of strategies that will lead to adequate sustainable funding for the maintenance and development of polytechnic libraries should be encouraged. According to Enstua-Mensah (2010) strategic thinking on the part of librarians would play an important role in resource mobilization.

Capacity building: Mishra (1995) asserts that continuing education of library staff and skills development play a crucial role in the management of libraries. According to her, academic libraries must recruit and retain highly skilled personnel that have the vision, determination and passion to collaborate to share knowledge and experiences. Entsua-Mensah supports this stance citing peer-to-peer training 
programmes where personnel from similar libraries are attached to others with better skills in specialised areas in building the capacity of the staff

\section{Conclusion}

There is no institution that has enough money to maintain and operate a Library satisfactorily. A library as stated by Ranganathan is a "growing organism", and as libraries grow change becomes inevitable. Therefore the argument that a Library is able to satisfy most user needs is empty without some means of learning about those unmet needs that are never expressed. Academic library co-operation is now regarded as an essential national infrastructure and many countries in Europe, Asia and America have established dedicated high performance National Research and Education Networks (NRENs), to maximise it. For example there is JANET in UK, NorduNet in Scandinavia, CERNET in China and SINET in Japan. All these have proven to be appropriate mechanisms to maximize information and to make effective use of resources.

Admittedly, libraries are facing daunting challenges due to the proliferation of resources in varying formats. Users' need are changing so are libraries. To survive the 21 century, it is increasely becoming important for the polytechnic libraries to co-operate in order to keep abreast with developments in the digital age.

\section{References}

Abass, I. K., (2005). Resource Sharing among Public University Libraries in Ghana. A Dissertation submitted to the Department of Information Studies, University of Ghana, Legon,Accra, Ghana,pp.2.

Agyei, A.E., (2010). Academic Librarianship in a Transformational Age: Problems and Prospects. Conference for the Committee of University Librarians and their Deputies, pp. 4.

Aina,L.O.,(2004). Library and Information Science Text for Africa. Third World Information Services Ltd, Ibadan, pp. 76.
Akwa, C., (2005). Collection Management at the Balm Library. A Dissertation submitted to the Department of Information Studies, University of Ghana,Legon, Accra, Ghana,pp.2.

Alemna, A.A., (2001). The Need for Marketing and Total Quality Management Strategies in Libraries in Ghana, INSPEL 35, No.4, pp. 266.

Asamoah, H., (1998). Mission of the Academic Libraries in Ghana in the 21st Century. Proceedings of the Seminar for Academic Librarians, pp.3.

Badu,E.E.,(1993).The Impact of the Use of Microcomputers on the University of Ghana Library, Library Review, Vol.42, No.5, pp.23.

Entsua-Mensah,C.,(2010). Academic and Research Libraries in Transition: Coping with the Emerging Trends. Committee of University Librarians and their Deputies, pp. 3-11.

Evans, E., and Saponaro,M.Z. ,(2005). Developing Library and Information Centre Collection: Library and Information Science Text Series, Libraries Unlimited,(4th ed.), pp.58.

Mishra,S., (1995). Marketing of Library and Information Services and Product: Old Wine in New Bottle. Library Herald, Vol.58, No.2,pp. 128.

Odini,C.,(1994). Collection Development: The Experience of Kenya Polytechnic Library, Library Management, Vol.15,No.4, pp.12, 14.

Patterson A. (2009) Research Support Through Resource Sharing: Challenges and Opportunities for Irish Academic Libraries. IFLA ,Vol.28 ,No.7,pp. 87.

White, B., (1986). Information for All: Access and Availability. Proceedings of the Annual Conference of the Institute of Information Scientist,pp. 27,37.

Wilson, T., and Marterson, K., (1970). Within the Context of Libraries. Library Review, pp. 56.

Yakubu, H., (2010). Academic and Research Libraries in Transition. Conference of the Committee of University Librarians and their Deputies, pp.2. 